\title{
Intercomparison of stratospheric nitrogen dioxide columns retrieved from ground-based DOAS and FTIR and satellite DOAS instruments over the subtropical Izana station
}

\author{
Cristina Robles-Gonzalez ${ }^{1, a}$, Mónica Navarro-Comas ${ }^{1}$, Olga Puentedura ${ }^{1}$, Matthias Schneider $^{3}$, Frank Hase ${ }^{3}$, \\ Omaira Garcia $^{2}$, Thomas Blumenstock ${ }^{3}$, and Manuel Gil-Ojeda ${ }^{1}$ \\ ${ }^{1}$ Atmospheric Research and Instrumentation Branch. National Institute for Aerospace Technology (INTA), \\ Ctra. Ajalvir s/n, Torrejón de Ardoz, 28850 Madrid, Spain \\ ${ }^{2}$ Izaña Atmospheric Research Center (IARC), Meteorological State Agency (AEMET), Tenerife, Spain \\ ${ }^{3}$ Institute of Meteorology and Climate Research - Atmospheric Trace Gases and Remote Sensing, \\ Karlsruhe Institute of Technology, Karlsruhe, Germany \\ ${ }^{a}$ currently at: Meteorological State Agency (AEMET), Madrid, Spain
}

Correspondence to: Cristina Robles-Gonzalez (croblesg@aemet.es)

Received: 7 February 2016 - Published in Atmos. Meas. Tech. Discuss.: 21 March 2016

Revised: 18 July 2016 - Accepted: 8 August 2016 - Published: 9 September 2016

\begin{abstract}
A 13-year analysis (2000-2012) of the $\mathrm{NO}_{2}$ vertical column densities derived from ground-based (GB) instruments and satellites has been carried out over the Izaña NDACC (Network for the Detection of the Atmospheric Composition Change) subtropical site. Ground-based DOAS (differential optical absorption spectroscopy) and FTIR (Fourier transform infrared spectroscopy) instruments are intercompared to test mutual consistency and then used for validation of stratospheric $\mathrm{NO}_{2}$ from OMI (Ozone Monitoring Instrument) and SCIAMACHY (SCanning Imaging Absorption spectroMeter for Atmospheric CHartographY). The intercomparison has been carried out taking into account the various differences existing in instruments, namely temporal coincidence, collocation, sensitivity, field of view, etc. The paper highlights the importance of considering an "effective solar zenith angle" instead of the actual one when comparing direct-sun instruments with zenith sky ones for a proper photochemical correction. Results show that $\mathrm{NO}_{2}$ vertical column densities mean relative difference between FTIR and DOAS instruments is $2.8 \pm 10.7 \%$ for a.m. data. Both instruments properly reproduce the $\mathrm{NO}_{2}$ seasonal and the interannual variation. Mean relative difference of the stratospheric $\mathrm{NO}_{2}$ derived from OMI and DOAS is $-0.2 \pm 8.7 \%$ and from OMI and FTIR is $-1.6 \pm 6.7 \%$. SCIAMACHY mean relative difference is of $3.7 \pm 11.7$ and
\end{abstract}

$-5.7 \pm 11.0 \%$ for DOAS and FTIR, respectively. Note that the days used for the intercomparison are not the same for all the pairs of instruments since it depends on the availability of data. The discrepancies are found to be seasonally dependent with largest differences in winter and excellent agreement in the spring months (AMJ). A preliminary analysis of $\mathrm{NO}_{2}$ trends has been carried out with the available data series. Results show increases in stratospheric $\mathrm{NO}_{2}$ columns in all instruments but larger values in those that are GB than that expected by nitrous oxide oxidation. The possible reasons for the discrepancy between instruments and the positive trends are discussed in the text.

\section{Introduction}

Nitrogen dioxide $\left(\mathrm{NO}_{2}\right)$ is both a natural and anthropogenic constituent of the terrestrial atmosphere. In the stratosphere it plays an important role in the equilibrium of ozone through autocatalytic cycles (Crutzen, 1970) and by deactivating other ozone-depleting substances into their reservoir forms. In remote unpolluted regions, the most important contribution to the $\mathrm{NO}_{2}$ vertical column densities (VCDs) comes from the stratosphere. The spatial and vertical distribution in these regions was first studied in the 1970 s by ground-based 
(GB) differential photometry and spectroscopy (Brewer et al., 1973; Kerr and McElroy, 1976; Noxon, 1975). The measurements by differential optical absorption spectrometry (DOAS) at zenith, or DOAS technique (Platt and Stutz, 2008) have since been used in remote locations for $\mathrm{NO}_{2}$ longterm monitoring. Using the infrared spectral domain, Fourier transform infrared spectroscopy (FTIR) instrumentation was deployed in order to analyse atmospheric trace gases (Hendrick et al., 2012). A few decades ago, both instrumental techniques were joined together in the NDACC (Network for the Detection of Atmospheric Composition Change) (http: //www.ndsc.ncep.noaa.gov), a network developed to provide accurate and standardized long-term measurements of atmospheric trace gases.

The recent needs of having reliable data in near-real time to feed the forecasting models such as MACC-II (http: //www.gmes-atmosphere.eu/about/project/) makes the comparison of observations performed by using different techniques and the validation of satellite data using GB observations a valuable tool to assure the quality of both GB and satellite data and thus improve the model performance.

However, the intercomparison of remote-sensing instruments collected by independent instrumentation is not straightforward. A deep knowledge of the representativeness of the scanned air masses provided by each instrumental technique is required. Over the last years, a number of studies have focused on the comparison of satellite $\mathrm{NO}_{2} \mathrm{ob}-$ servations with GB instruments (FTIR and DOAS) in order to identify and quantify potential discrepancies. Gil et al. (2008) published a climatology of the stratospheric $\mathrm{NO}_{2}$ over the NDACC subtropical station Izaña and a preliminary comparison with SCIAMACHY satellite instrument, finding good agreement between them (1.1\% differences). Dirksen et al. (2011) compared more than 5 years (October 2004 to May 2010) of OMI (Ozone Monitoring Instrument) stratospheric $\mathrm{NO}_{2}$ from the OMI standard products (SP) and from the DOMINO algorithm with NDACC remote stations GB measurements, finding a mean difference of $13 \%$. Lambert et al. (2011) reported an agreement between GOME-2 and NDACC/UV-vis network over the Northern Hemisphere within 8-20\%, depending on the season and latitude. Adams et al. (2012) presented an intercomparison of GB and satellite $\mathrm{NO}_{2}$ columns at a Polar Canadian station (PEARL). The satellite data they used were OSIRIS, ACE-FTS v2.2 and ACE-FTS v3.0, which agreed with GB measurements within $20 \%$. However, very few publications include FTIR data in their comparisons. Wetzel et al. (2007) presented the validation of MIPASENVISAT $\mathrm{NO}_{2}$ data. They showed that the mean deviation between the FTIR measurements and MIPAS from July 2002 until March 2004 remains within $10 \%$ in Kiruna $\left(68^{\circ} \mathrm{N}\right)$ and over Harestua $\left(60^{\circ} \mathrm{N}\right)$ a mean negative bias of $15 \%$ have been presented for MIPAS UV-vis daytime comparisons. Hendrick et al. (2012) compared stratospheric $\mathrm{NO}_{2}$ datasets from the DOAS-based instrument SAOZ and FTIR- based instrument Bruker with satellite DOAS instruments, namely GOME, SCIAMACHY and GOME-2, at northern midlatitudes over Jungfraujoch from 1990 to 2009. They observed FTIR minus GB DOAS mean relative differences of about $-7.8 \pm 8.2 \%$ and satellite minus GB DOAS mean relative differences of $0.9 \pm 8.8 \%$ for GOME, $1.9 \pm 11.5 \%$ for SCIAMACHY and $2.3 \pm 11.6 \%$ for GOME-2. Recently, Belmonte Rivas et al. (2014) revised the stratospheric $\mathrm{NO}_{2}$ data retrieved from satellite instruments. They found discrepancies in stratospheric $\mathrm{NO}_{2}$ obtained on nadir mode when compared with the "limb" ones. Globally, SCIAMACHY was underestimated by $0.5 \times 10^{15}$ molec $\mathrm{cm}^{-2}$ whereas OMI data were found to be $0.6 \times 10^{15}$ molec $\mathrm{cm}^{-2}$ too large. They also found a temperature dependence affecting the retrieval via the air mass factor (AMF). Therefore, in order to be able to explain such differences, Marchenko et al. (2015) and van Geffen et al. (2015) carried out a thorough revision of the algorithms used to retrieve $\mathrm{NO}_{2}$ from OMI data. These studies proposed improved descriptions of the wavelength calibration and reference spectra in the DOAS spectral fitting. Temperature variability in the subtropical stratosphere is small as compared to higher latitudes. The amplitude of the seasonal wave in the mid-stratosphere is $4 \mathrm{~K}$ peak to peak (Gil et al., 2008), thus minimizing the temperature-dependence impact on the satellite retrieval.

The goal of this paper is to extend the previous GB to satellite intercomparisons to lower latitudes, including DOAS and FTIR GB techniques. Thirteen years of data, 2000 to 2012, from the Izaña NDACC subtropical station have been used for this purpose. Once the agreement of GB instruments is proven, their measurements are used for the validation of OMI and SCIAMACHY satellite observations. In this work a new correction method with a high impact on photochemical active species is also introduced and applied to minimize the effect of the different scanned air mass when different kind of observations are used.

The use of two GB independent measurements techniques is also helpful for long-term studies since confidence is gained when searching trends, which are usually small compared with the seasonal cycle. Additionally, extra information can be obtained on the heights where trends are observed if the vertical sensitivity of the instruments is not identical, as is the case with DOAS and FTIR. Previous studies on $\mathrm{NO}_{2}$ trends are not conclusive.

Gruzdev and Elokhov (2009) found a hemispherical dependence on the sign of the stratospheric $\mathrm{NO}_{2}$ trend. A positive trend was found over the middle latitudes of the Southern Hemisphere, in good agreement with expectations, whereas the trend over the Northern Hemisphere was negative, in disagreement with the increase of emissions of nitrous oxide $\left(\mathrm{N}_{2} \mathrm{O}\right)$, which is a precursor of $\mathrm{NO}_{2}$. Hendrick et al. (2012) also found negative trends over Jungfraujoch for the period 1990-2009. Gil-Ojeda et al. (2015) found a hemispherical and latitude dependence on the sign and magnitude of the trend based on four GB DOAS stations. Northern latitudes 
display a positive trend whereas trends are negative in the southern latitudes. The picture is consistent with MIPAS trends analysis for $\mathrm{O}_{3}$ (i.e. Eckert et al., 2014). At present, this subject is under debate.

The work is organized as follows: Sects. 2 and 3 present the DOAS and FTIR techniques, respectively, their advantages and limitations as well as the basics of the algorithms used to extract $\mathrm{NO}_{2}$ column abundances. Section 4 gives a brief review of the satellite instruments SCIAMACHY and $\mathrm{OMI}$ and the algorithms whose results have been used along this work. In Sect. 5 the main characteristics of the Izaña Observatory are highlighted. The procedure for the intercomparison is explained in Sect. 6 and the results and discussion can be found in Sect. 7 .

\section{DOAS: technique and instrument}

As previously mentioned, the DOAS technique (Platt and Stutz, 2008) has been extensively used in last decades to measure stratospheric $\mathrm{NO}_{2}$ since the pioneering works of Noxon (1975) and Syed and Harrison (1981). The technique is based on the analysis of the absorption of sky radiation by the gas under consideration, providing that the magnitude of the absorption structure varies with the wavelength. For species of interest with the load of mass located in the stratosphere, the spectrum of the sky is taken during the twilight to enhance the effect of the stratospheric absorption and minimize the tropospheric contribution. The analysis is based on a linear fit of the log ratio of the sky background intensity spectrum with respect to a reference (non-absorbing) spectrum. In practice a spectrum obtained with the same ground instrument at high sun is used as a reference spectrum. Then the $\mathrm{NO}_{2}$ content in this spectrum is estimated by a Langleyplot method (Platt and Stutz, 2008).

INTA (National Institute for Aerospace Technology, http:// www.inta.es/atmosfera/33/menu.aspx) started measurements of $\mathrm{NO}_{2}$ at the Izaña Atmospheric Observatory (IZO), managed by the Meteorological State Agency (Agencia Estatal de Meteorologia, AEMET, Spain, http://izana.aemet.es/), in 1993 and in the framework of NDACC in 1998. Since then, two DOAS instruments have been covering the period of measurements at Izaña Observatory. During the period 1998 to 2010, the RASAS spectrometer was in operation. The instrument is based on an EGG\&1453A 1024 photodiode array detector controlled by an EGG 1461 on a Jarrel-Ash Monospec 18 spectrograph. Scattered light at zenith was collected by a baffled cylinder through a quartz fibre bundle. A diffraction grating of 600 grooves $\mathrm{mm}^{-1}$ provided a spectral range of 340-600 nm for $\mathrm{NO}_{2}$ and $\mathrm{O}_{3}$ observations with an average full width at half maximum (FWHM) resolution of $1.3 \mathrm{~nm}$. The spectrograph and detector were housed in a thermostatized hermetic container, keeping the spectrograph at a constant temperature maintaining the alignment of the spectra with time.
A 3-year overlapping period was used to ensure the series continuity. However, no corrections to the data were needed since the agreement between instruments was excellent (see Gil et al., 2008). A more detailed description of the instrument can be found in Gil et al. (2008).

Data from RASAS instrument from day number 186/2006 through day number 129/2010 are corrected from a continuous degradation of the PDA detector, which resulted in an apparent decrease of $4.3 \%$ per year. Correction was performed thanks to the alternative measurements of the scanning spectrometer (first instrument in the field), in operation since the beginning of the measurements, and the overlapping with RASAS-II, in operation since day 15/2010.

Since 2010 the instrument was replaced by a MAXDOAS (Multi Axis Differential Optical Absorption Spectroscopy) capability spectrometer (RASAS-II). The spectral range is $415-530 \mathrm{~nm}$, thus covering the largest $\mathrm{NO}_{2}$ spectral bands. It is based on a Shamrok SR-163i spectrograph and a $1024 \times 255$ pixel DU420A-BU Andor Idus CCD camera. A detailed description of RASAS II instrument can be found in Puentedura et al. (2012) and Gomez et al. (2014).

The analysis of the spectra was performed using software developed at INTA based on the standard DOAS technique. A detailed explanation of the analysis routine can be found in Gil et al. (2008). DOAS settings for $\mathrm{NO}_{2}$ column retrieval follow NDACC UV/Vis Working Group recommendations (Hendrick et al., 2012; Van Roozendael et al., 2012). A set of six reference spectra has been included: $\mathrm{O}_{3}, \mathrm{NO}_{2}, \mathrm{H}_{2} \mathrm{O}$ and $\mathrm{O}_{4}$. The Raman scattering cross section was generated by the Win-DOAS package (Fayt and Van Roozendael, 2001) from the Raman theory. Finally, the inverse of the reference spectrum was included as a pseudo cross section to account for stray light inside the spectrograph and detector residual dark current. The AMF used for the conversion of $\mathrm{NO}_{2}$

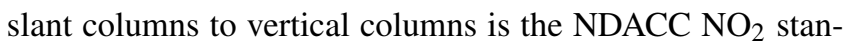
dard AMF available on the NDACC UV-vis web page (http: //ndacc-uvvis-wg.aeronomie.be/) and based on the Lambert et al. (1999) climatology of $\mathrm{NO}_{2}$ profiles. This climatology consists of a Fourier harmonic decomposition of UARS HALOE v19 and SPOT-4 POAM-III v2 $\mathrm{NO}_{2}$ profile data records (Van Roozendael and Hendrick, 2012). Further details are shown in Table 1.

\section{FTIR: technique and instrument}

Ground-based FTIR measurements are performed at IZO since 1999 (Schneider et al., 2005) under a collaborative effort between KIT (Karlsruhe Institute of Technology, http:// www.imk-asf.kit.edu/english/) and the Spanish Atmospheric Research Centre of AEMET. It is part of the NDACC. In 2005 a Bruker IFS 125 HR spectrometer (García et al., 2012) was installed in a container and equipped with a solar tracker at Izaña Observatory. The solar tracker is controlled by a camera and Camtracker software (Gisi et al., 2011). Solar 
Table 1. DOAS spectrometers settings.

\begin{tabular}{ll}
\hline Fitting interval & $450-533 \mathrm{~nm}$ \\
\hline $\mathrm{NO}_{2}$ cross section & Vandaele et al. (1998), 220 ${ }^{\circ} \mathrm{K}$ \\
$\mathrm{O}_{3}$ cross section & Bogumil et al. (2001), 223 ${ }^{\circ} \mathrm{K}$ \\
$\mathrm{H}_{2} \mathrm{O}$ cross section & HITRAN (Rothman et al., 2009) \\
$\mathrm{O}_{4}$ cross section & RASAS spect. Greenblatt (1990), room temp. \\
& RASAS-II spect. Hermans (1999), room temp. \\
Ring effect & Chance and Spurr (1997) \\
Orthogonalization polynomial & Third degree \\
Offset correction & Inverse of the reference \\
AMF calculation & NDACC NO 2 AMF lookup tables \\
Determination of residual amount & Modified Langley plot \\
in reference spectrum & (Vaughan et al., 1997) \\
SZA range for twilight averaging & 89-91 SZA (approx. six measurements) \\
of & \\
vertical columns & \\
\hline
\end{tabular}

transmission spectra are recorded in the spectral range of 2.4 to $13.5 \mu \mathrm{m}$ using InSb and MCT detectors. In order to improve the signal-to-noise ratio, the NDACC optical filter set is used. The instrumental line shape (ILS) is monitored on a regular basis using cell measurements and LINEFIT software (Hase et al., 1999). Spectra are analysed using PROFFIT retrieval code (Hase et al., 2004). PROFFIT includes a forward calculation model and an inversion tool to retrieve profiles and column amounts of trace gases from atmospheric spectra. The NDACC harmonized retrieval scheme is applied. As spectroscopic data the HITRAN 2008 line parameters (Rothman et al., 2009) are used. Daily NCEP data are used for pressure and temperature. Profiles and column amounts of trace gases like $\mathrm{H}_{2} \mathrm{O}, \mathrm{HDO}, \mathrm{CH}_{4}, \mathrm{~N}_{2} \mathrm{O}, \mathrm{CFC}-11$, CFC-12, $\mathrm{O}_{3}, \mathrm{HNO}_{3}, \mathrm{ClONO}_{2}, \mathrm{HCl}, \mathrm{HF}, \mathrm{NO}$ and $\mathrm{NO}_{2}$ can be derived from the infrared spectra. For $\mathrm{NO}_{2}$ a spectral microwindow, providing weak $\mathrm{NO}_{2}$ lines superimposed to a strong broadband methane absorption, of around $2914.5 \mathrm{~cm}^{-1}$ is fitted. The $\mathrm{NO}_{2}$ total column retrieved using this algorithm is mainly sensitive to the stratospheric abundance.

\section{Satellite instrumentation}

\subsection{SCIAMACHY}

SCIAMACHY was a satellite imaging spectrometer on board ENVISAT platform in operation from March 2002 to April 2012. It measured backscattered, transmitted or reflected radiation from the Earth surface and atmosphere with a moderately high resolution $(0.2$ to $1.5 \mathrm{~nm})$ in the wavelength range of 240 and $1700 \mathrm{~nm}$ for global remote sensing of trace gases, aerosols and clouds. It measured in nadir, limb and occultation modes (Bovensmann et al., 1999; Burrows and Chance, 1991) with a swath of $960 \mathrm{~km}$ across track with a resolution of $30 \times 60 \mathrm{~km}^{2}$ in the nadir mode. Detailed information about operation characteristics of SCIAMACHY can be found at http://www.sciamachy.org/. The stratospheric $\mathrm{NO}_{2}$ is retrieved by using the DOAS technique in the spectral region of $425-450 \mathrm{~nm}$. The data used in this paper have been generated by the Institute of Environmental Physics (IUP) of the University of Bremen algorithm v2.0 (http://www.iup. uni-bremen.de/doas/scia_no2_data_acve.htm) (Sussman et al., 2005) based on the work of Richter and Burrows (2002), for GOME $\mathrm{NO}_{2}$. SCIAMACHY stratospheric $\mathrm{NO}_{2}$ values within $200 \mathrm{~km}$ around the station are included in the dataset. $\mathrm{NO}_{2}$ cross sections used in the analysis are those by Vandaele et al. (1998), which are also used for DOAS retrieval. SCIAMACHY data have not been corrected for cross-section temperature dependence. Assuming a dependence of 0.3 to $0.5 \% \mathrm{~K}^{-1}$ (Bucsela et al., 2013; Boersma et al., 2004) for the Izaña latitude, the maximum error due to this effect is 1.2 to $2 \%$.

\subsection{OMI}

OMI is a hyperspectral imaging instrument (Levelt et al., 2006) on board AURA that measures the backscattered Earth radiation in the UV-vis spectral range (from 264 to $504 \mathrm{~nm}$ ) with a spectral resolution between 0.42 and $0.63 \mathrm{~nm}$. It has a spatial resolution of $13 \mathrm{~km}$ along track by $24 \mathrm{~km}$ cross track for the nadir pixels. The swath width is about $2600 \mathrm{~km}$, providing daily global coverage.

The OMI stratospheric $\mathrm{NO}_{2}$ data have been computed with the NASA Standard Product OMNO2 algorithm (version 2) (Bucsela et al., 2013), applying the DOAS technique in the spectral range of 405 to $465 \mathrm{~nm}$ (Boersma et al., 2002; Bucsela et al., 2006). As in the case of SCIAMACHY, OMI stratospheric $\mathrm{NO}_{2}$ values within $200 \mathrm{~km}$ around the station are included in the dataset. The cross sections used in the analysis are $\mathrm{NO}_{2}$ from Vandaele et al. (1998), $\mathrm{O}_{3}$ are from Burrows et al. (1999) and $\mathrm{H}_{2} \mathrm{O}$ from Harder and Brault (1997). An empirical temperature correction factor is 
applied to the $\mathrm{NO}_{2}$ absorption cross sections similarly to the factors used by Boersma et al. (2002, 2004). For more information about the stratospheric $\mathrm{NO}_{2}$ scientific algorithm see Bucsela et al. (2013). Recently, thorough revisions of the spectral fitting algorithms were presented in Marchenko et al. (2015) and van Geffen et al. (2015). Here we use datasets available to us in the beginning of 2013, so without the updates presented in those papers. The studies from Marchenko and van Geffen suggest that the improved $\mathrm{NO}_{2}$ slant column densities and, consequently, the stratospheric $\mathrm{NO}_{2}$ columns are reduced by $10-35 \%$ relative to data used in our study.

\section{Izaña Atmospheric Observatory}

The IZO is a high mountain NDACC station located on Tenerife island in the subtropical North Atlantic Ocean $\left(28.3^{\circ} \mathrm{N}, 16.5^{\circ} \mathrm{W} ; 2370 \mathrm{~m}\right.$ a.s.1.), where DOAS and FTIR instruments are in operation since 1993 and 1999, respectively. IZO is run by the Izaña Atmospheric Research Centre (IARC, www.izana.aemet.es), belonging to State Agency of Meteorology of Spain (Agencia Estatal de Meteorología, AEMET).

IZO is located above a quasi-permanent temperature inversion layer established between 800 and $1500 \mathrm{~m}$ a.s.l. associated to the trade-winds regime. The inversion layer separates the moist marine boundary layer from the dry free troposphere and works as a natural barrier for local and regional pollution (Cuevas et al., 2015, and references therein). Thereby, the $\mathrm{NO}_{2}$ VCD can be considered as dominated by stratospheric $\mathrm{NO}_{2}$ with relatively minor contribution from the troposphere.

\section{Comparison methodology}

The signal of remote-sensing instruments using direct or diffuse solar radiation as a source is a weighted average of rays crossing the entire atmosphere through different paths. The averaging kernel (AVK) matrix defines the relation between the retrieved quantities and the true atmospheric state (Eskes and Boersma, 2003; Rodgers, 2004) and it can be viewed as the sensitivity of the instrument to the trace gas in the different layers.

Large differences in AVK profiles between DOAS, FTIR and satellite techniques would lead to uncertainties difficult to quantify and could result in a more complicated intercomparison (Adams et al., 2012; Dirksen et al., 2011; Hendrick et al., 2012; Peters et al., 2012; Sussmann et al., 2005, among others). This, however, is not the case. Figure 1 shows how all considered instruments have their maximum sensitivity in the stratosphere and how the tropospheric effect is minimum. AVKs are plotted for the diurnal period of measurements of each instrument, DOAS at solar zenith angle (SZA) of 89$91^{\circ}$, FTIR for SZA $50^{\circ}$ a.m. to $50^{\circ}$ p.m. and satellites around noon. The DOAS tropospheric response is almost zero since

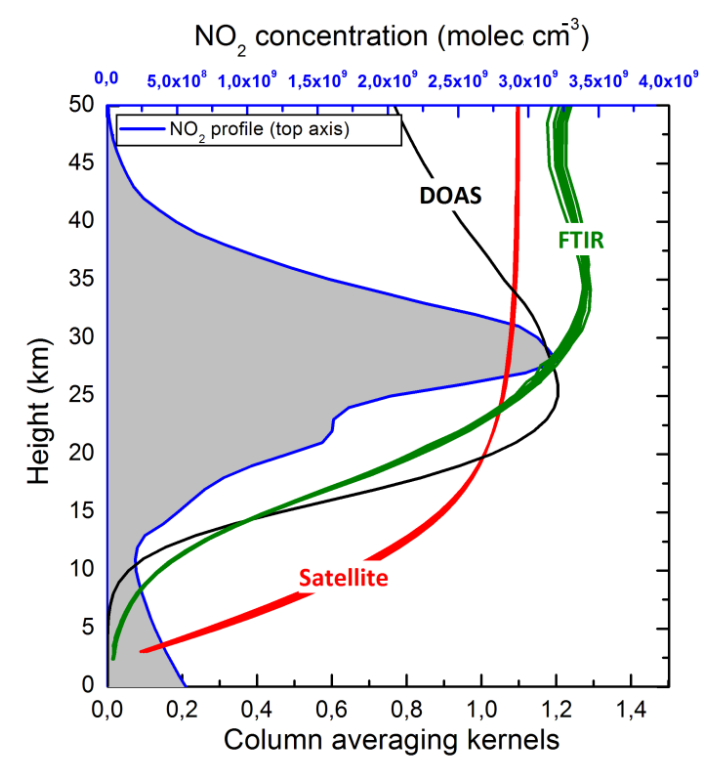

Figure 1. Typical averaging kernels of DOAS (black line), FTIR (green line) and satellite (red line) instruments for the diurnal period of measurements. The shaded area represents a $\mathrm{NO}_{2}$ vertical profile (top axis) over Izaña obtained from the American Standard Atmosphere (US Standard Atmosphere, 1976, US Government Printing Office, Washington, DC, 1976) for the tropics.

at twilight the effective scattering height, which is the height where the rays are scattered downward to the instrument, is located in the lower stratosphere. The contribution of the lower layers of the troposphere to the nadir satellites signal is also small since scattering is still large at $440 \mathrm{~nm}$. In any case, satellite algorithms take into account the effect of the troposphere to eliminate it from the stratospheric $\mathrm{NO}_{2}$ results to avoid potential pollution episodes. The $\mathrm{NO}_{2}$ signatures used by the FTIR retrieval are rather weak. Therefore, the retrieval approach of a scaling a priori profile is used. Due to the fact that the absorption contribution of stratospheric $\mathrm{NO}_{2}$ is less pressure-broadened, it has per molecule a larger impact on the least-squares fit than a tropospheric contribution. In addition, the $\mathrm{NO}_{2}$ signatures are surrounded by strong $\mathrm{CH}_{4}$ lines, and the imperfect spectroscopic description of the wings generated by these lines requires the fit of additional empirical background parameters, which results in a further decrease of the retrieval sensitivity with respect to tropospheric $\mathrm{NO}_{2}$. Therefore all intercompared instruments are highly sensitive at the altitude range where the $\mathrm{NO}_{2}$ bulk is located and minimize the potential differences near the surface that may occur due to pollution events. The AVK assessment suggests that $\mathrm{NO}_{2}$ columns measured by nadir satellites, DOAS and FTIR can be directly compared. Being the station in a remote location in the free troposphere at $2370 \mathrm{~m}$ a.s.l., well above the major source of pollution, the column data are representative of the stratospheric $\mathrm{NO}_{2}$. For that reason, the satellite product "stratospheric column" has been used here. 
The algorithms to generate atmospheric products from DOAS and FTIR instruments require an "a priori" $\mathrm{NO}_{2}$ profile. DOAS employs the $\mathrm{NO}_{2}$ climatology obtained from a Fourier harmonic decomposition of UARS HALOEv19 and SPOT-4 POAM-IIIv2 profiles data (Lambert et al., 1999), whereas FTIR utilizes the output of the WACCM climatic model. To test the influence of the profile used on the final products, DOAS AMFs have been obtained by means of the WACCM profile for a case study. Results of the comparison show that the selection of the profiles has a maximum impact of $6 \%$ on the retrieved columns.

The importance of a proper collocation when intercomparing instruments from different platforms and techniques has recently been recognized. The spatial coincidence, the field of view, the data vertical and horizontal smoothing as well as the location of the effective air mass have to be taken into account. The instruments should observe the same air mass in the atmosphere (spatial coincidence). This requirement is not always easy to fulfil when comparing instruments based on different techniques. In cases where the spatial coincidence is not possible, the comparison of the instruments can be performed, taking into account the impact of such differences on the data. The "effective location" is the surface projection of the studied air parcel. For instance, DOAS instruments measure scattered light at zenith during twilight. As the stratospheric $\mathrm{NO}_{2}$ layer is centred at about $25-30 \mathrm{~km}$ height (orange layer in Fig. 2a), the effective stratospheric $\mathrm{NO}_{2}$ mass measured by the instrument is about $300 \mathrm{~km}$ toward the sun direction. Two effects are observed from this figure: the first one is that when satellite nadir data are to be compared with DOAS, the selection of the ground pixel for collocation must be done by taking into account the location of the DOAS effective air mass. Figure $2 \mathrm{~b}$ shows the surface projection of the central point of the effective air masses for DOAS and FTIR. DOAS zenith sky scans $300 \mathrm{~km}$ towards the east and west in morning and dusk, respectively, whereas FTIR directsun measurements are representative of the stratosphere in the surroundings of the station. There is also dependence on the season: about $300 \mathrm{~km}$ in latitude change from summer to winter solstices. The size of the air masses scanned by each instrument is also a factor affecting the degree of agreement. While FTIR scans a narrow field of view, satellite footprints cover an area of few decades to hundreds of squared kilometres and for comparison all measurements falling within a given area are considered. In our study a circle of about $300 \mathrm{~km}$ around IZO has been considered.

At the tropical-subtropical latitudes the $\mathrm{NO}_{2}$ spatial variability in the stratosphere is low and the impact of these effects on the intercomparisons is small. From tests carried out over the area with SCIAMACHY data it has been found almost no zonal gradients and meridional gradients of $2.0 \times 10^{13}$ molec $^{-2}{ }^{-2}$ per degree, in subtropical unpolluted areas, representing $0.84 \%$ per latitude degree of the column. Therefore the impact of the changing scanned volume with season might have a maximum effect of $3 \%$ of the column.
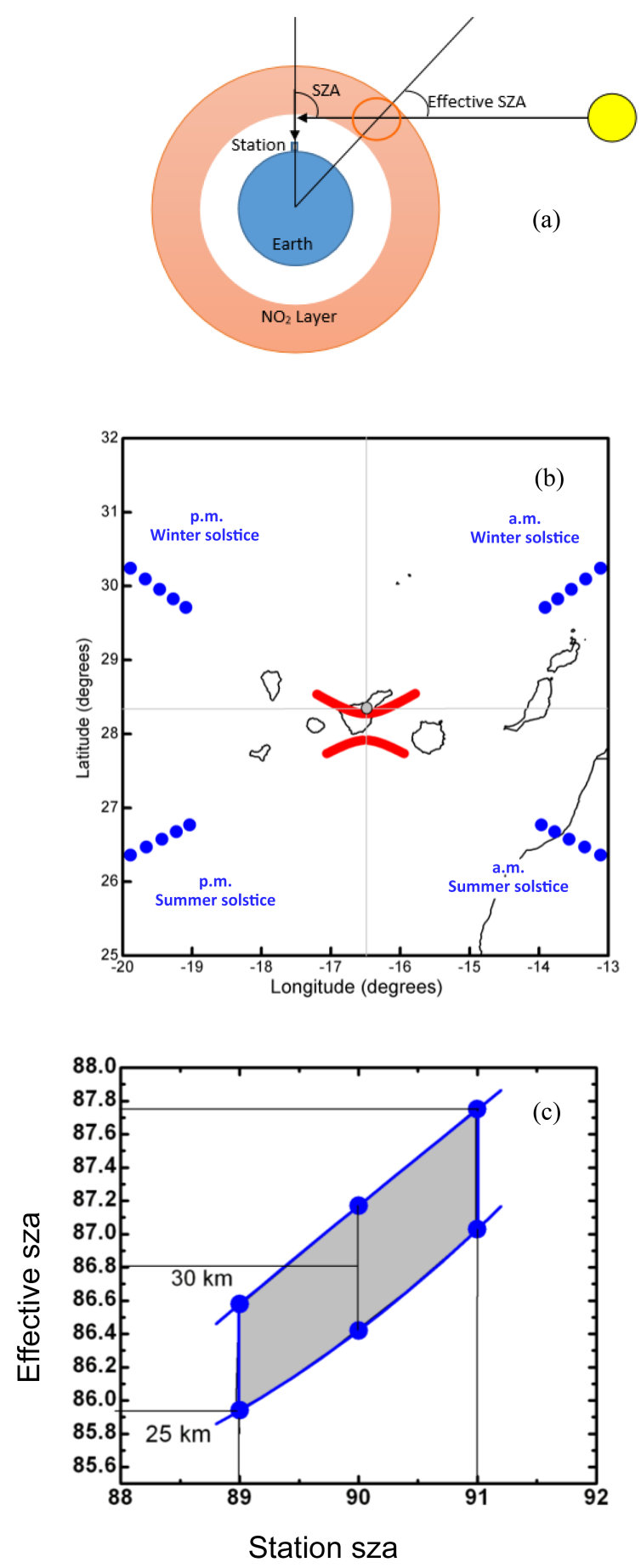

Figure 2. Representation of the effective $\mathrm{NO}_{2}$ air mass (a) scanned by the DOAS instrument. (b) Surface projection of scanned air masses for FTIR (red) and DOAS (blue) instruments for winter and summer solstices. Calculation assumes the bulk of the $\mathrm{NO}_{2}$ layer at $30 \mathrm{~km}$ height. (c) Effective solar zenith angles vs. local zenith angle for 25 and $30 \mathrm{~km} \mathrm{NO}_{2}$ bulk height. 
Around the Canary Archipelago there are small longitudinal differences associated to coastal pollution that will be discussed in Sect. 7.

The second effect is that the effective solar zenith angle at the effective air mass area is about $3^{\circ}$ lower than the actual $\mathrm{SZA}$ at the station (local SZA). Figure $2 \mathrm{c}$ shows the local and the effective SZA (ESZA) of the observed stratospheric $\mathrm{NO}_{2}$ layer (in grey colour). In photochemically active species such as $\mathrm{NO}_{2}$ a SZA-dependent correction has to be applied to correct for the diurnal variation in the column and refer the measurements to a common time. This effect was already mentioned by Gil et al. (2008). In addition, Adams et al. (2012) observed that over polar areas the SZA-dependent correction is particularly significant in spring and fall. As previously mentioned, the effective DOAS $\mathrm{NO}_{2}$ air mass is located in sun direction and the ESZA at the working latitude is $86.8^{\circ}$ for a.m. and p.m. measurements. The ESZA has been obtained as the SZA corresponding to the intersection point of the effective ray at $90^{\circ}$ with the height of the maximum $\mathrm{NO}_{2}$ concentration in the annual mean profile. The effective ray, defined as the single ray equivalent to the integration of all rays arriving at the instrument, was computed by the INTA ray-tracing radiative transfer model in single scattering and spherical mode with no refraction included (Sarkissian et al., 1995). The mean vertical distribution above $17 \mathrm{~km}$ was obtained by annual averaging of mean morning profiles from the HALOE and POAM-II data (Lambert et al., 1999) whereas for lower altitudes the output of the SLIMCAT box model was used (Denis et al., 2005). No tropospheric $\mathrm{NO}_{2}$ has been considered. In the northern subtropical region the "effective height" does not vary much and neither does the "effective SZA". In Fig. 2c the effect of the height assumption on the effective SZA is shown. A change of $5 \mathrm{~km}$ in height of the bulk of the layer ( 25 to $30 \mathrm{~km}$ ) at SZA $90^{\circ}$ over the station makes the "effective SZA" to change from 86.4 to $87.2^{\circ}$. The error due to such a change would be $\pm 0.4^{\circ}$, which means $1.4-1.5 \%$ in the column, depending on the season. We estimate this error as the upper limit. In Fig. 3 the theoretical $\mathrm{NO}_{2}$ photochemical behaviour over Izaña is shown together with the time overpasses of the OMI and SCIAMACHY instruments. As the $\mathrm{NO}_{2} \mathrm{VCD}$ varies along the day, densities measured at different times must be corrected to be referred to a common time. In the early morning $\mathrm{NO}_{2}$ is strongly reduced until it reaches a new daytime $\mathrm{NO}-\mathrm{NO}_{2}$ equilibrium. Then, it increases during the daytime in a nearly linear way mainly due to $\mathrm{N}_{2} \mathrm{O}_{5}$ photodissociation. At Tenerife, the $\mathrm{NO}_{2}$ $\mathrm{VCD}$ at $86.8^{\circ}$ a.m. is $19 \%$ lower than at $90^{\circ}$ a.m. The daytime increase is of about $1 \times 10^{14} \mathrm{molec} \mathrm{cm}^{-2} \mathrm{~h}^{-1}$. For that reason the $\mathrm{NO}_{2} \mathrm{VCD}$ at mean OMI overpass time is 9.8 and $6.5 \%$ larger than SCIAMACHY overpass time for winter and summer, respectively. In our work the stratospheric $\mathrm{NO}_{2}$ from FTIR a.m. data (up to 12:00 UTZ), SCIAMACHY and OMI instruments has been photochemically corrected to the DOAS a.m. measurement time, while FTIR p.m. data (after 12:00 UTZ) have been corrected to the DOAS p.m. using the

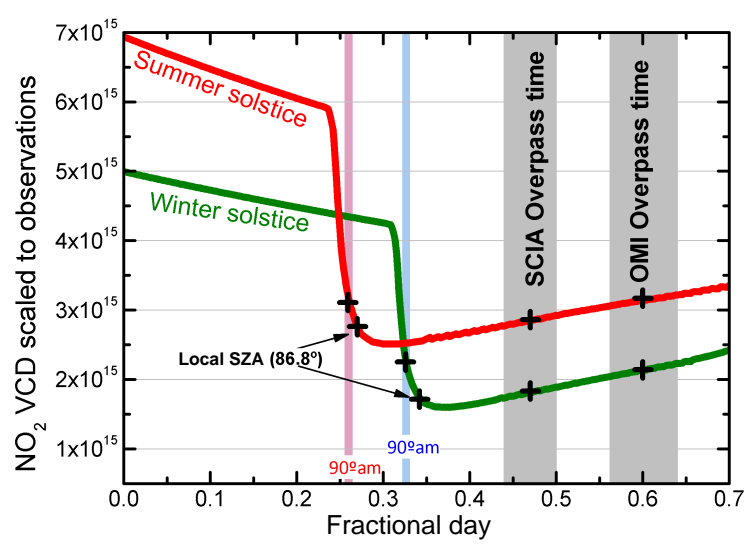

Figure 3. Example of the $\mathrm{NO}_{2}$ photochemical behaviour from the SLIMCAT box model over Izaña. Red and green lines are the $\mathrm{NO}_{2}$ VCD daily variation at the summer and winter solstices, respectively. Grey areas are the time overpasses of SCIAMACHY and OMI instruments (adapted from Gil et al., 2008).

BIRA-IASB (Belgian Institute for Space Aeronomy) stacked box photochemical model PSCBOX (Hendrick et al., 2004, 2012), daily initialized with SLIMCAT 3-D CTM chemical and meteorological fields (Chipperfield, 2006) extracted for $\left(30^{\circ} \mathrm{N}, 0^{\circ} \mathrm{E}\right)$ for the $2000-2009$ period. Based on these simulations, a climatology of $\mathrm{NO}_{2} \mathrm{VCD}$ diurnal variation is built and correction factors appropriate for the photochemical matching between FTIR and DOAS observations are extracted from it. The ESZAs have been used for this purpose.

Another potential source of discrepancy might arise from the local meteorology diurnal variation. FTIR takes measurements in the hours around noon, when the mountain anabatic winds transport air masses from the marine boundary layer to the level of the station, as can be seen from "in situ" measurements (Gil-Ojeda et al., 2015). However, since the upwelling takes place in a shallow layer near the surface, the impact on the overall column seems to be very low. The DOAS instrument measures during twilight, when a breeze, should one exist, is minimal. In summary, we expect the diurnal upwelling to have a negligible impact in the comparison.

\section{Results}

Figure 4 displays the cross-correlation of FTIR (a.m. data), SCIAMACHY and OMI data vs. DOAS by considering the SZA over the station and the ESZA for the collocation criteria correction described in previous sections. The figures show that in all three cases the agreement strongly improves when the photochemical correction due to temporal collocation is referred to the ESZA, where the bulk of the $\mathrm{NO}_{2}$ is located $\left(86.8^{\circ}\right)$, rather than the SZA of the DOAS instrument $\left(90^{\circ}\right)$. In all cases ESZA-corrected points fit better the $1: 1$ line for the range of $\mathrm{NO}_{2}$ values. The slope is slightly reduced in all cases but the ESZA correction improves the 
Table 2. Results of the linear fit of DOAS vs. FTIR, OMI and SCIAMACHY NO $2 \mathrm{VCD}$ for $\mathrm{SZA}=90^{\circ}$ and $\mathrm{ESZA}=86.8^{\circ}$.

\begin{tabular}{lrr|rr|rr}
\hline & \multicolumn{2}{c}{ DOAS-FTIR } & \multicolumn{2}{c}{ DOAS-SCIAMACHY } & \multicolumn{2}{c}{ DOAS-OMI } \\
\cline { 2 - 7 } & $90^{\circ}$ & $86.8^{\circ}$ & $90^{\circ}$ & $86.8^{\circ}$ & $90^{\circ}$ & $86.8^{\circ}$ \\
\hline \multicolumn{7}{c}{ Linear fit } \\
\hline Interc. & $1.12 \times 10^{15}$ & $0.92 \times 10^{15}$ & $0.77 \times 10^{15}$ & $0.64 \times 10^{15}$ & $1.41 \times 10^{15}$ & $0.82 \times 10^{15}$ \\
Slope & 0.77 & 0.66 & 0.81 & 0.70 & 0.74 & 0.66 \\
Adj. R-square & 0.65 & 0.64 & 0.56 & 0.56 & 0.73 & 0.75 \\
\hline & \multicolumn{7}{c}{ Gaussian fit } \\
\hline Center & $3.66 \times 10^{14}$ & $3.77 \times 10^{13}$ & $2.23 \times 10^{14}$ & $-7.21 \times 10^{13}$ & $6.02 \times 10^{14}$ & $-5.31 \times 10^{12}$ \\
Width & $3.22 \times 10^{14}$ & $3.16 \times 10^{14}$ & $4.04 \times 10^{14}$ & $3.40 \times 10^{14}$ & $2.83 \times 10^{14}$ & $2.66 \times 10^{14}$ \\
\hline
\end{tabular}
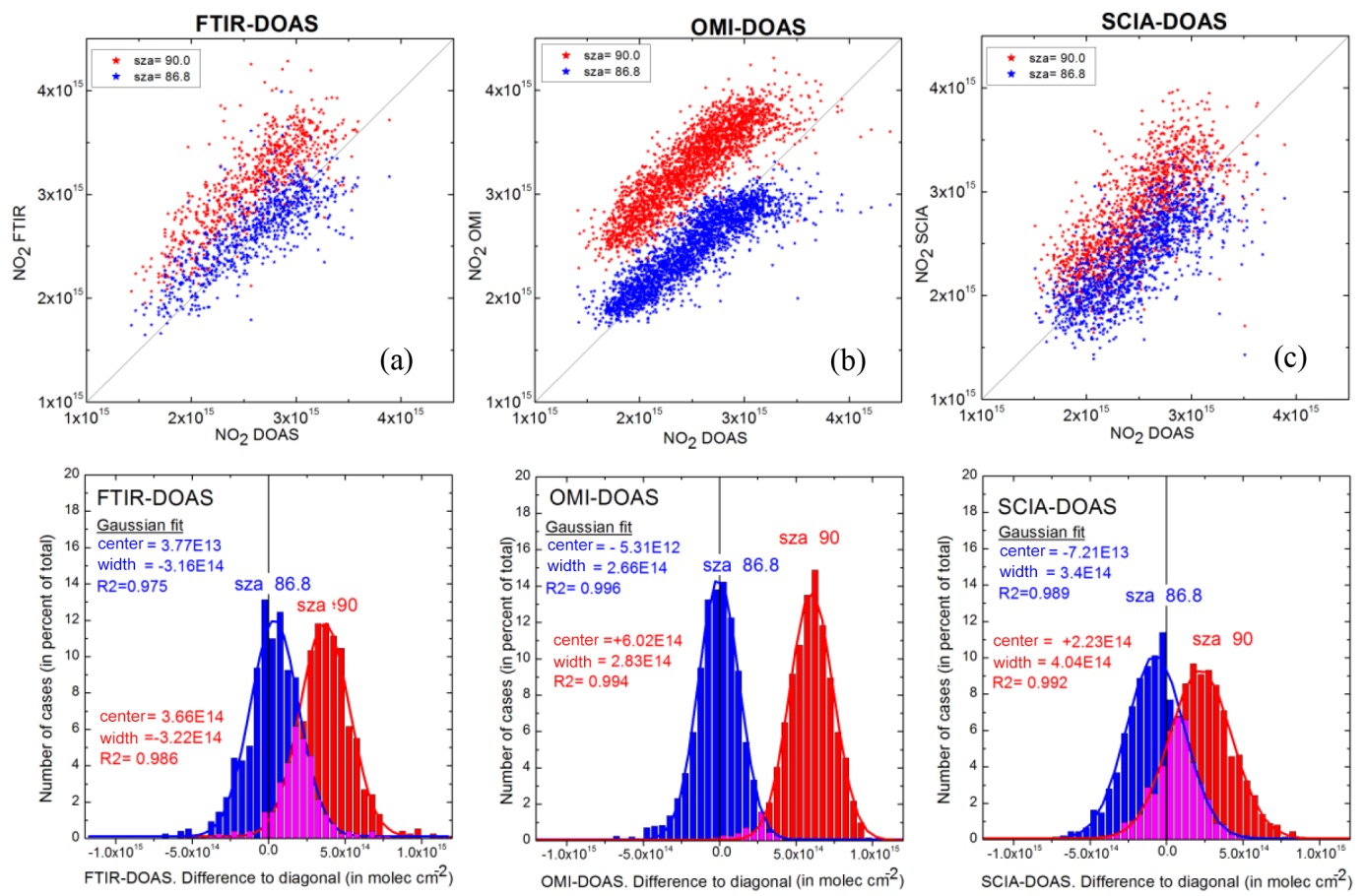

Figure 4. Upper panel: scatter plot of the $\mathrm{NO}_{2}$ measured by DOAS instrument ( $x$ axis) and (a) FTIR, (b) OMI and (c) SCIAMACHY in the $y$ axis. The effective $\mathrm{SZA}=90^{\circ}$ is presented in red stars and effective $\mathrm{SZA}=86.8^{\circ}$ in blue stars. Solid diagonal represents the ideally perfect agreement. Lower panel: frequency distribution of the distance of each cross-correlation point to the diagonal considering for the photochemical correction the local SZA at $90^{\circ}$ (red) and the effective SZA at $86.8^{\circ}$ (blue). See text for details.

comparison. In Fig. 4 (lower panel) the frequency analysis of the distance from the point $P(X$, DOAS) to the $1: 1$ line is represented, where $X$ is all other instruments. In Table 2 the parameters of the Gaussians and the linear fits are shown. The mean distance with respect to the $1: 1$ line of the FTIRDOAS represented by the Gaussian frequency distribution improves from $3.66 \times 10^{14}$ to $3.77 \times 10^{13} \mathrm{molec} \mathrm{cm}^{-2}$, the OMI-DOAS from $6.02 \times 10^{14}$ to $-5.31 \times 10^{12}$ and the SCIAMACHY-DOAS from $2.23 \times 10^{14}$ to $-7.21 \times 10^{13}$.

From now on, stratospheric $\mathrm{NO}_{2}$ converted to $90^{\circ}$ is not used any more in this work. All following results have been computed with the ESZA correction.
The FTIR $\mathrm{NO}_{2}$ photochemically corrected data are averaged to have one value per twilight. Figure 5a presents the monthly mean variation of the $\mathrm{NO}_{2}$ measured by the DOAS and the FTIR instruments. The lower values on the plot correspond to a.m. values whereas the higher ones are p.m. $\mathrm{NO}_{2}$ values. In Fig. $5 \mathrm{~b}$ the relative difference between both instruments is presented in percent. In general, results show a good agreement. a.m. values compare better than p.m. values with $2.8 \pm 10.7$ and $11.7 \pm 9.5 \%$, respectively, even though mean values are within the standard deviation in both cases. At least a fraction of the differences found in the p.m. data can be real $\mathrm{NO}_{2} \mathrm{VCD}$ differences because, at noon and during the 


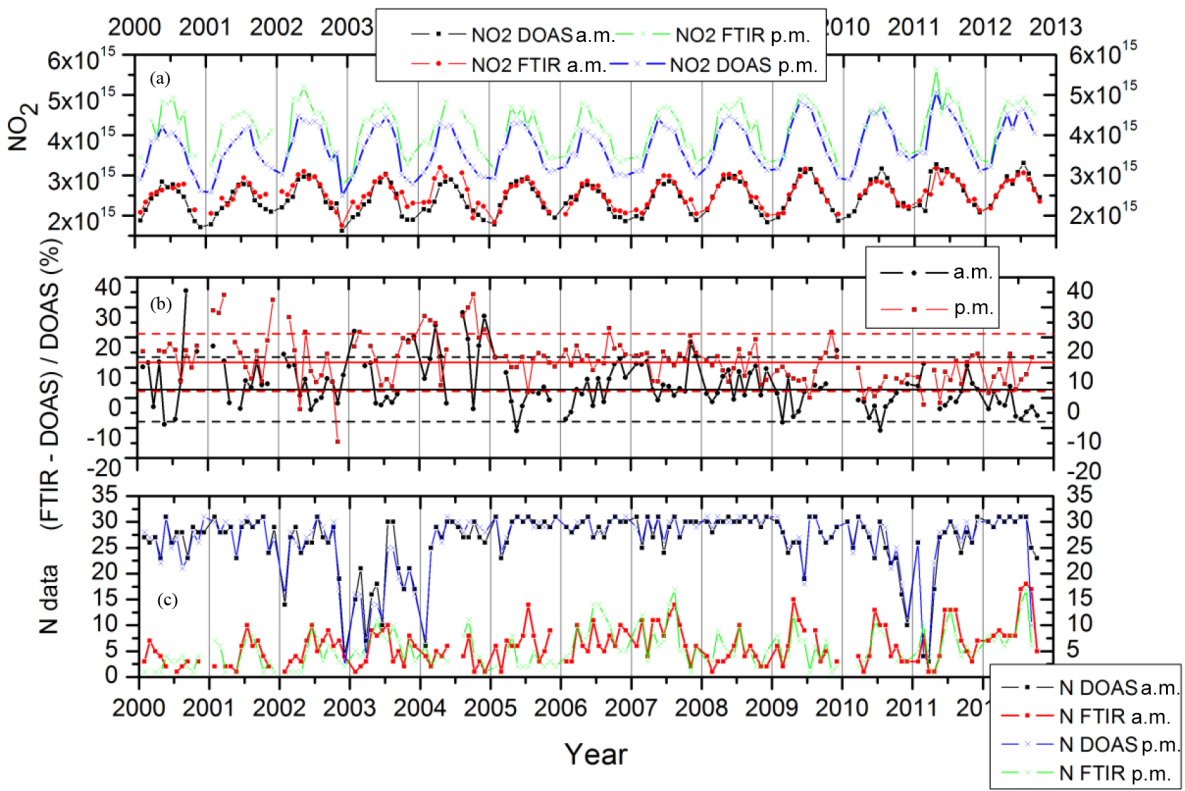

Figure 5. (a) Monthly mean evolution of $\mathrm{NO}_{2}$ VCD from DOAS (black dots for a.m. and blue for p.m.) and FTIR (red dots for a.m. and green for p.m.). (b) Relative differences: solid line presents the mean relative difference and the dash lines represent the mean relative difference plus and minus the standard deviation in black for a.m. and in red for p.m. values. (c) Shows the number of days used to compute the monthly mean.

afternoon, high- $\mathrm{NO}_{2}$ boundary layer air masses are upwelled by the forced heating of the surface (upslope breeze) and can be seen by the direct-sun FTIR, even though its response to tropospheric pollution is small. Additionally, air masses located to the west, in mid-Atlantic, are representative of the background condition, whereas the eastern ones have slightly more $\mathrm{NO}_{2}$ in the troposphere, contributing to 3-4\% larger columns (Fig. 6). The treatment of the $\mathrm{NO}_{2}$ diurnal variation in the box model used for the correction might have a contribution as well, specifically the $\mathrm{N}_{2} \mathrm{O}_{5}$ photodissociation rate. These results show the limitations existent when comparing remote-sensing data obtained with independent techniques sampling non-identical air masses at non-identical times. Figure $5 \mathrm{~b}$ also shows a change in the FTIR-DOAS behaviour at the beginning of 2005 both in a.m. and p.m. data. In that year the FTIR instrument was switched from a Bruker IFS $120 \mathrm{M}$ to a Bruker IFS 120/5HR, which is less noisy than its predecessor. The improvement is observed by a decrease in the relative differences between instruments. It is also observed that FTIR $\mathrm{NO}_{2}$ values are, in general, higher than DOAS $\mathrm{NO}_{2}$ values. Dirksen et al. (2011) found similar results over Izaña, in contrast to Hendrick et al. (2012) who found FTIR measurements lower than DOAS SAOZ instrument by $7.8 \pm 8.2 \%$ on average over the NDACC Jungfraujoch station. Such differences are attributed to uncertainties related to the respective spectroscopic parameters and differences in sensitivity profiles. Adams et al. (2012) compared FTIR results with SAOZ and PEARL (Polar Environment Atmospheric Research Laboratory) GB instruments operat- ing in the UV and the visible. They found that FTIR measures less $\mathrm{NO}_{2}$ than the DOAS instruments by $12.2 \pm 19.2 \%$.

Figure 7 shows the OMI comparison with DOAS and FTIR measurements. OMI stratospheric $\mathrm{NO}_{2}$ data located $300 \mathrm{~km}$ around the Izaña station were used. Figure $7 \mathrm{~b}$ shows the relative differences in percent of satellite minus GB $\mathrm{NO}_{2}$ values. In general, the results compare extremely well within $-0.2 \pm 8.7 \%$ for the OMI-DOAS validation and $-1.6 \pm 6.9 \%$ for the OMI-FTIR (see Table 3). Dirksen et al. (2011) validated $\mathrm{OMI} \mathrm{NO}_{2}$ with independent GB measurements from October 2004 to May 2010. Over Izaña, they presented OMI vs. FTIR relative differences from 4 to $7 \%$, which are similar to the present paper's results, while for the OMI-DOAS relative differences are larger, in the range of 26 to $29 \%$. A possible reason for that difference is the photochemical correction applied to the $\mathrm{NO}_{2}$ DOAS data to be compared with the OMI data. FTIR measurements used in this study, however, were close in time to the OMI overpass and no corrections to the data were made. Belmonte Rivas et al. (2014) found that OMI stratospheric $\mathrm{NO}_{2}$ columns were higher than those obtained with the SCIAMACHY and GOME-2 instruments. They claim that the bias of the OMI $\mathrm{NO}_{2}$ slant columns are due to ancillary data used in the retrieval such as the selection of absorption crosssection spectra, solar reference spectrum, Ring spectra and approaches for wavelength calibration. Therefore, a thorough revision of the retrieval methodologies is necessary. In that sense, recently, major efforts have been made in order to improve the algorithms that compute the $\mathrm{NO}_{2}$ from OMI data 


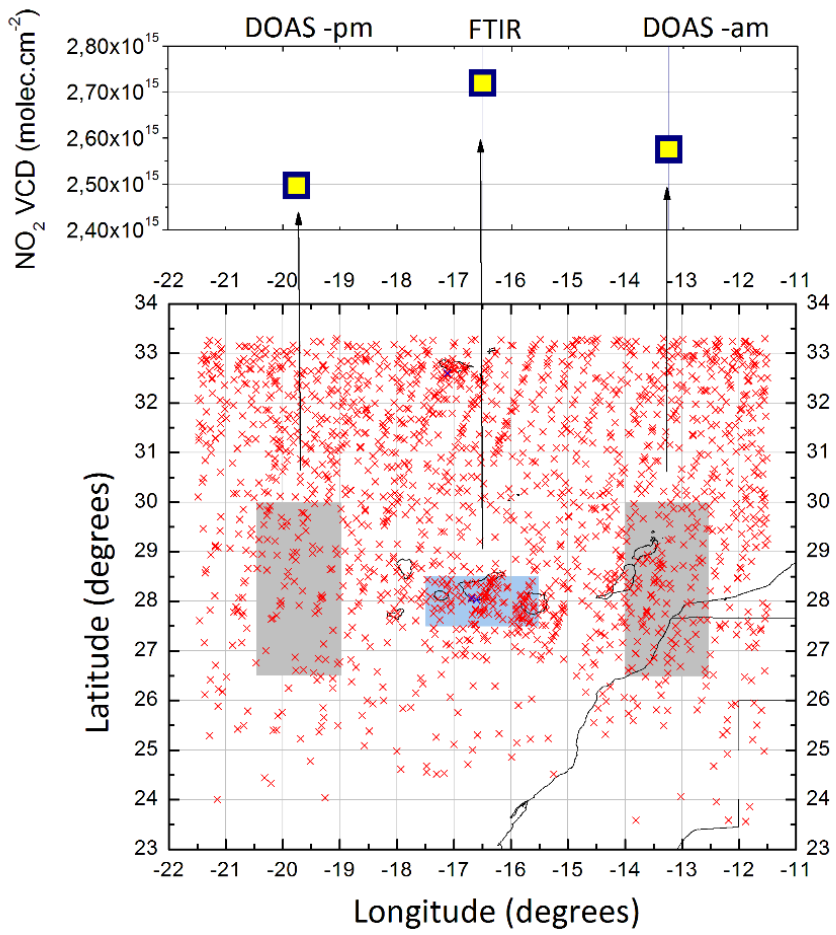

Figure 6. Areas where DOAS (grey rectangles) and FTIR (blue rectangle) are scanning the stratosphere. A complete year of SCIAMACHY $\mathrm{NO}_{2}$ vertical column density (VCD) with values above $3.3 \times 10^{15}$ molec $\mathrm{cm}^{-2}$ is shown (red crosses). The value is arbitrarily selected to provide a hint of the pollution influence over the area.

Table 3. Statistics of the relative difference of the stratospheric $\mathrm{NO}_{2}$ from ground-based and satellite instruments in percent.

\begin{tabular}{lrrr}
\hline & No. & Mean & $\begin{array}{r}\text { Standard } \\
\text { deviation }\end{array}$ \\
\hline FTIR-DOAS (a.m.) & 746 & 2.8 & 10.7 \\
FTIR-DOAS (p.m.) & 698 & 11.7 & 9.5 \\
OMI-DOAS & 2355 & -0.2 & 8.7 \\
OMI-DOAS (EAM text) & 1298 & 0.2 & 8.6 \\
SCIA-DOAS & 1326 & -3.7 & 11.7 \\
OMI-FTIR & 540 & -1.6 & 6.9 \\
SCIA-FTIR & 314 & -5.7 & 11.0 \\
\hline
\end{tabular}

${ }^{*}$ EAM is effective air mass.

(Marchenko et al., 2015; van Geffen et al., 2015). Marchenko et al. (2015) showed a reduction of the stratospheric $\mathrm{NO}_{2}$ VCD of 20-30\%. Van Geffen et al. (2015) found a reduction of the root mean square of about $32 \%$. Remarkably, in this work such discrepancies were not found. This issue is still open and further work is required to understand the discrepancies.

Even though the results shown in our paper agree well with the literature, a test exercise has been carried out to im- prove the quality of the validation exercise. Following the recommendation made in Sect. 6 about the effective air mass (EAM) for the OMI-DOAS validation, instead of using all the OMI data retrieved $200 \mathrm{~km}$ around the station, we have only selected the data whose centre longitude falls in between the station and the sun (a.m. values). In that way the OMI measurements closer to the effective DOAS air mass are included in the validation. The new result of the validation is $0.2 \pm 8.6 \%$, which presents a minor improvement of the validation (see in Table 3), proving that this effect is not crucial for the stratospheric $\mathrm{NO}_{2}$ because its longitudinal variation is small. Therefore this test exercise has not been applied to SCIAMACHY data that are presented next.

The stratospheric $\mathrm{NO}_{2}$ dataset from SCIAMACHY has been compared with DOAS and FTIR data as well. The monthly mean interannual variation is presented in Fig. 8a. The relative mean difference in percent of the stratospheric $\mathrm{NO}_{2}$ from SCIAMACHY, DOAS and FTIR instruments is shown in Fig. 8b. Results show that SCIAMACHY agrees within $-3.7 \pm 11.7 \%$ with DOAS and within $-5.7 \pm 11.0 \%$ for the comparison with FTIR results. A summary of the results are shown in Table 3. Note that the days used for the intercomparison are not the same for all the pairs of instruments since the intercomparison depends on the availability of data. Results are reasonable, even though SCIAMACHY generates lower values than the GB instruments, in contrast with previous studies. Gil et al. (2008) reported SCIAMACHY minus DOAS differences of $1.1 \%$ over Izaña, but with SCIAMACHY being higher than DOAS values. Hendrick et al. (2012) also report higher SCIAMACHY $\mathrm{NO}_{2}$ values than SAOZ over Jungfraujoch of $1.9 \pm 11.5 \%$. The most probable reason for the discrepancies is related to the photochemical correction carried out to the SCIAMACHY results. In the present study, the ESZA has been used for the correction, leading to lower values of stratospheric $\mathrm{NO}_{2}$ than those obtained using the local SZA in previous analysis. Taking into account the differences in techniques and time of measurements, SCIAMACHY and GB data are in good agreement.

The agreement of the different instruments is found to be seasonally dependent (Fig. 9). There is little scattering and differences around zero on spring months (AMJ), whereas discrepancy increases towards the winter months. All instruments remain within $10 \%$ or better. Surprisingly, GB instruments behave differently than the satellite ones. OMI and SCIAMACHY show the seasonal maximum in June, quite in phase with the solar radiation. Ground-based instruments, in contrast, display the maximum in July and large columns are found in September as well. Gil et al. (2008) found the $\mathrm{NO}_{2}$ column over Izaña for the period 1994-2005 to be modulated by the middle-stratospheric temperature. However, the maximum of the secondary $\mathrm{NO}_{2}$ cycle is located in March and cannot explain the July peak. This effect is currently under study. 


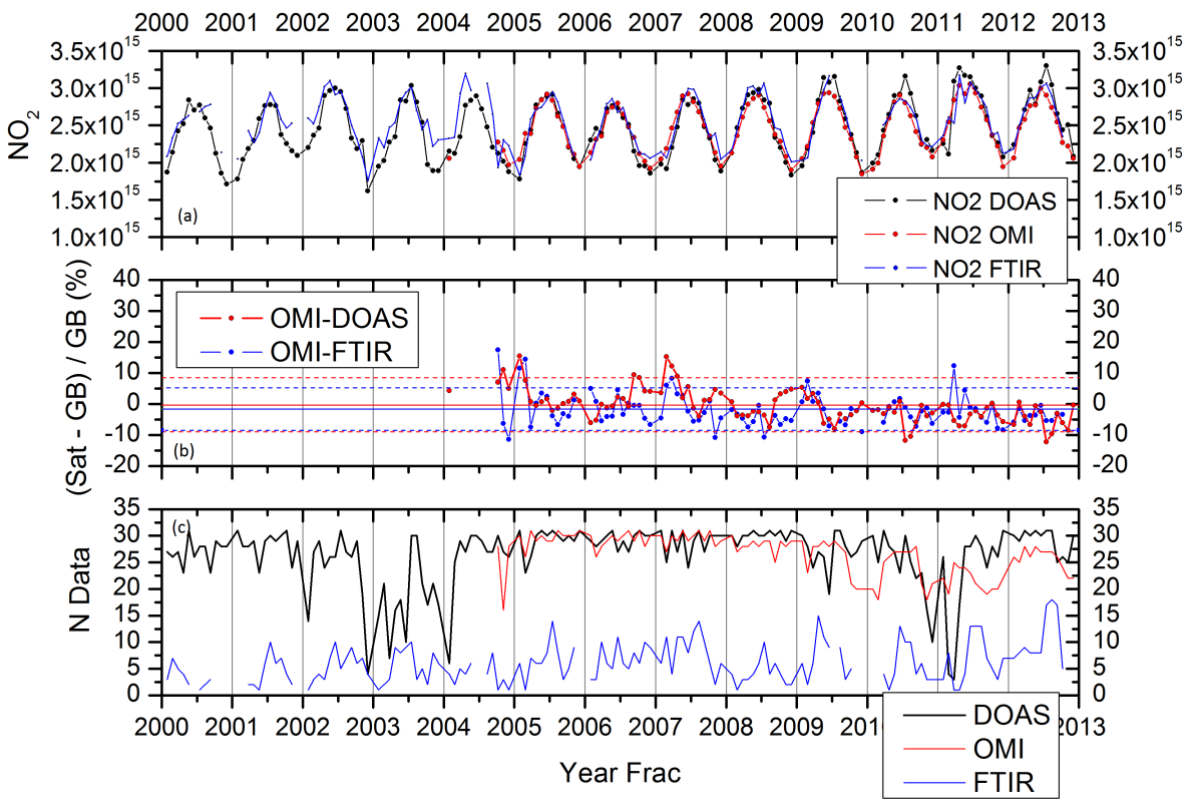

Figure 7. Same as Fig. 5 but for OMI vs. DOAS and FTIR (only a.m. data). Note that the scale in the top plot is different from Fig. 5.

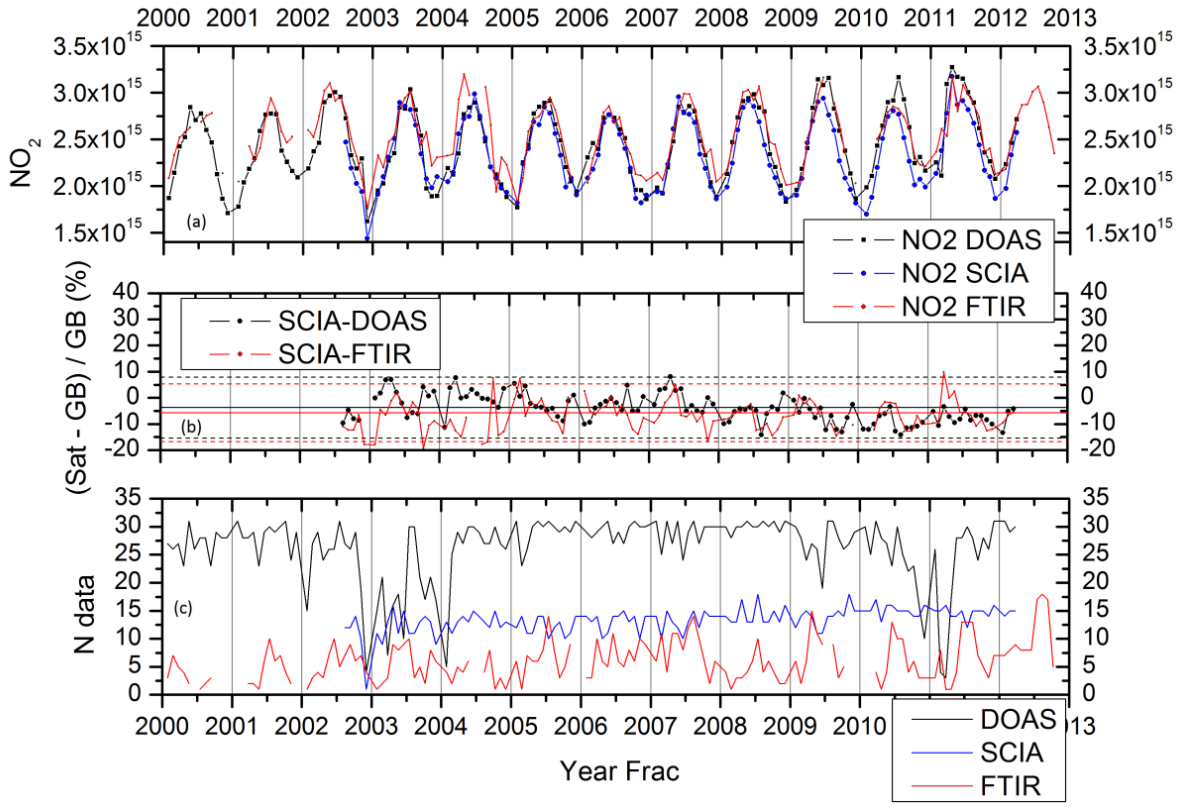

Figure 8. Same as Fig. 5 but for SCIAMACHY vs. DOAS and FTIR (only a.m. data). Note that the scale in the top plot is different from Fig. 5.

A preliminary estimation of stratospheric $\mathrm{NO}_{2} \mathrm{VCD}$ trends has been made by means of a linear regression calculation. In order to avoid the $\mathrm{NO}_{2}$ seasonal dependence, the calculation has been performed for each month (see Fig. 10). In the study, neither the influence of the solar cycle (quasibiennial oscillation) nor that of the stratospheric temperature is included. Over our study station the evolution of the $\mathrm{NO}_{2}$ is dominated by the seasonal waves; therefore, the omission of the quasi-biennial oscillation and the stratospheric temperature has a minor effect. A more detailed study on $\mathrm{NO}_{2}$ trends is ongoing in order to improve the preliminary trends presented here and to better understand the results.

All instruments show positive trends in $\mathrm{NO}_{2}$ stratospheric column. The DOAS instrument presents the largest trend with 10 to $15 \%$ decade $^{-1}$ significant at the $90 \%$ confidence level depending on the month for the period 2000 to 2012, 

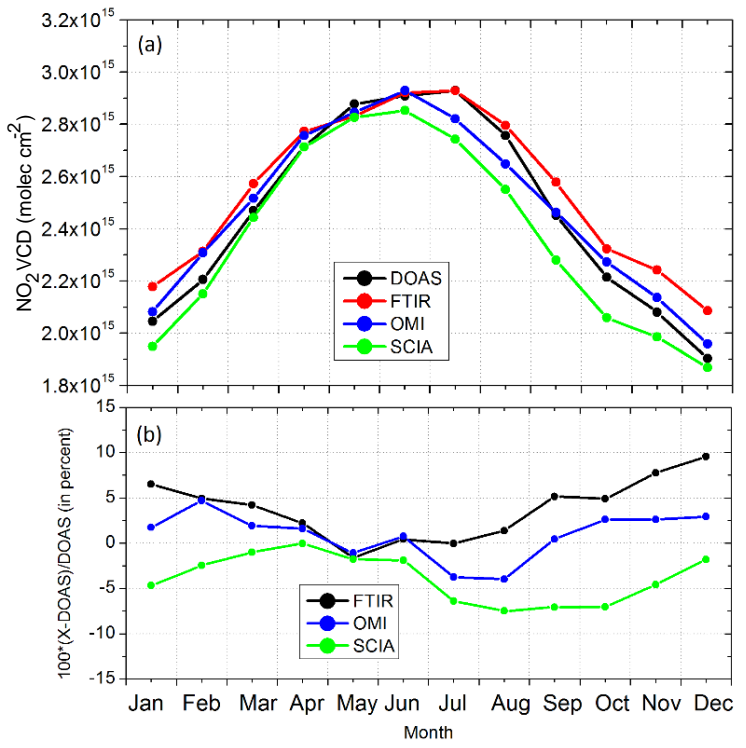

Figure 9. (a) Seasonal variation of $\mathrm{NO}_{2}$ derived from DOAS (black), FTIR (red), OMI (blue) and SCIAMACHY (blue-green). (b) $\mathrm{NO}_{2}$ relative difference from the instruments with respect to DOAS.

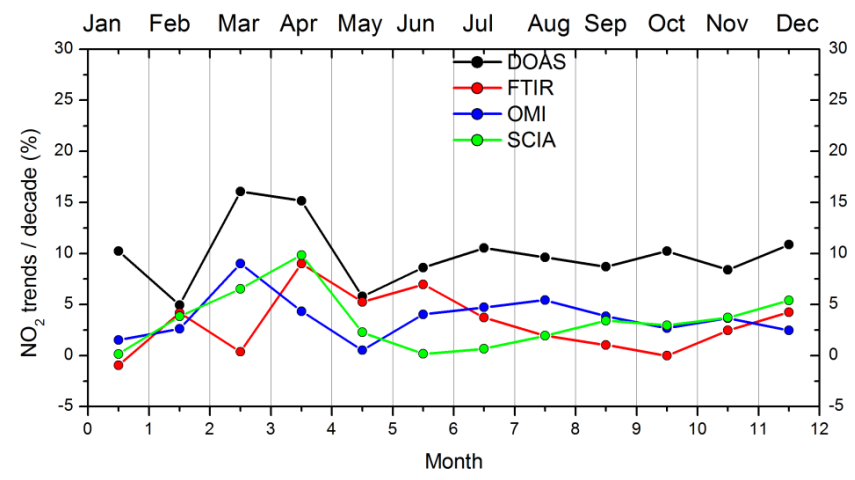

Figure 10. $\mathrm{NO}_{2}$ monthly trends from year 2000 to 2012 .

while FTIR, OMI and SCIAMACHY trends show values up to $10 \%$ decade $^{-1}$ on individual months, but lower on average and with small confidence levels. The preliminary results of the FTIR trend is significant at the $60 \%$ of confidence level, OMI trend at the $80 \%$ and SCIAMACHY at the $60 \%$ of confidence level. On the annual mean, DOAS trend is larger by a factor of 3 than the rest of the instruments. These positive trends exceed by far those expected by the nitrous oxide oxidation. $\mathrm{N}_{2} \mathrm{O}$ is increasing at a nearly steady rate of $2.5 \%$ decade $^{-1}$ (Liley et al., 2000). It is also of opposite sign to those found over the Jungfraujoch station in the Swiss Alps (Hendrick et al., 2012). The observed trend could be slightly biased if a trend in the stratospheric temperature has occurred during the analysed period. A recent report based on the most extensive satellite data to date found little or no trend in global lower stratospheric temperature from 1995 to
2013 (Seidel et al., 2015). ERA-Interim data at $10 \mathrm{hPa}$ examined by the authors show a nonsignificant negative trend of $0.2 \mathrm{~K} /$ decade, which should have no impact on the calculated $\mathrm{NO}_{2}$ trend.

The observed increase at tropical-subtropical latitudes is in agreement with the analysis of the MIPAS global $\mathrm{NO}_{y}$ data for the period 2002 to 2012 and the output of the WACCM model for the same period of time (Funke et al., 2015). Since the global $\mathrm{NO}_{y}$ remains almost constant, the observed increase has been attributed to a displacement of the subtropical barrier as a consequence of stratospheric temperature changes (Eckert et al., 2014). The maximum trend occurs in late winter and beginning of spring, supporting the dynamic explanation.

\section{Conclusions}

$\mathrm{NO}_{2}$ total columns derived from two GB independent techniques, DOAS and FTIR, from the NDACC network over Izaña $\left(28^{\circ} \mathrm{N}, 16^{\circ} \mathrm{W} ; 2370 \mathrm{~m}\right.$ a.s.l. $)$ have been intercompared for the period 2002-2012. Once mutual consistency has been proven, GB data have been used for OMI and SCIAMACHY validation of $\mathrm{NO}_{2}$ stratospheric product. The paper discussed the concepts of spatial representativeness of the data and potential discrepancies related to differences in sampled air mass volumes, and time of measurements. The importance of the use of the ESZA when comparing noon measurements with twilight measurements of photochemically active species is highlighted. For a gas with a bulk at $30 \mathrm{~km}$ height, the ESZA of a zenith DOAS with local SZA of 90 is $86.8^{\circ}$. After the correction of ESZA, the agreement between instruments improves significantly, strongly reducing mean differences in all cases. The FTIR-DOAS mean difference of the datasets ranges from $+2.8 \pm 10.7$ to $+11.7 \pm 9.5 \%$ for a.m. and p.m. data, respectively. Part of this difference is attributed to the photochemical box model used to reference to a common time of the day. For the satellite validation mean differences of $-0.2 \pm 8.7 \%$ are found for the OMI-DOAS and $-1.6 \pm 6.9$ for the OMI-FTIR comparisons. SCIAMACHY-DOAS shows a mean difference of about $-3.7 \pm 11.7$ and $-5.7 \pm 11.0 \%$ for SCIAMACHYFTIR. The seasonal cycle is well reproduced by all the instruments, with a dispersion increment during the winter months.

The agreement of the different instruments is found to be seasonally dependent. The differences are largest in winter months and almost disappear in spring (AMJ). Surprisingly, GB instruments display the seasonal maximum in July whereas satellites show it in June. A preliminary linear correlation analysis shows positive trends for all instruments above the rate of nitrous oxide oxidation. FTIR, SCIAMACHY and OMI mean annual trend is about $4 \%$ decade $^{-1}$ whereas DOAS observes $13.5 \%$ decade $^{-1}$. This large discrepancy is attributed to the DOAS high sensitivity to the 
lower stratosphere where the increase of dynamical origin seems to have been taking place.

\section{Data availability}

The data used in this work are publicly available: DOAS and FTIR data are available from the NDACC web page (http://www.ndsc.ncep.noaa.gov/); the SCIAMACHY data from http://www.iup.uni-bremen.de/doas/scia_no2_ data_acve.htm and OMI data are available from http: //avdc.gsfc.nasa.gov/index.php?site $=666843934 \& i d=13$.

Acknowledgements. This publication has been funded by the AVATAR project of the Spanish national funding Agency (MINECO: CGL2014-55230-R ). This work has been carried out in the frame of the NORS (Demonstration Network of Ground-Based Remote Sensing Observations in support of the Copernicus Atmospheric Service) project (funded by the European Community's Seventh Framework Programme (FP7/2007-2013) under grant agreement no. 284421; http://nors.aeronomie.be/) and has been partially supported by AMISOC project funded by the Spanish national funding Agency (CGL2011-24891). Authors acknowledge F. Hendrick from the BIRA-IASB Institute for making available the photochemical correction used in this paper, the Institute of Environmental Physics of the University of Bremen for the SCIAMACHY $\mathrm{NO}_{2}$ data and the Goddard Space Flight Center from NASA for the $\mathrm{OMI} \mathrm{NO}_{2}$ data. Comments from the editor, Folkert Boersma, significantly improved the paper. We also acknowledge Emilio Cuevas for the temperature data series he sent us.

Edited by: F. Boersma

Reviewed by: two anonymous referees

\section{References}

Adams, C., Strong, K., Batchelor, R. L., Bernath, P. F., Brohede, S., Boone, C., Degenstein, D., Daffer, W. H., Drummond, J. R., Fogal, P. F., Farahani, E., Fayt, C., Fraser, A., Goutail, F., Hendrick, F., Kolonjari, F., Lindenmaier, R., Manney, G., McElroy, C. T., McLinden, C. A., Mendonca, J., Park, J.-H., Pavlovic, B., Pazmino, A., Roth, C., Savastiouk, V., Walker, K. A., Weaver, D., and Zhao, X.: Validation of ACE and OSIRIS ozone and $\mathrm{NO}_{2}$ measurements using ground-based instruments at $80^{\circ} \mathrm{N}$, Atmos. Meas. Tech., 5, 927-953, doi:10.5194/amt-5-927-2012, 2012.

Aura Validation Center: EOS Aura OMI OMNO2 (Collection 3), available at: http://avdc.gsfc.nasa.gov/index.php?site= 666843934\&id=13, 2016.

Belmonte Rivas, M., Veefkind, P., Boersma, F., Levelt, P., Eskes, $\mathrm{H}$., and Gille, J.: Intercomparison of daytime stratospheric $\mathrm{NO}_{2}$ satellite retrievals and model simulations, Atmos. Meas. Tech., 7, 2203-2225, doi:10.5194/amt-7-2203-2014, 2014.

Blumenstock, T.: FTIR Izaña Total Clolumn, available at: ftp://ftp. cpc.ncep.noaa.gov/ndacc/station/izana/ames/ftir/, 2005-2008.

Boersma, K. F., Bucsela, E. J., Brinksma, E. J., and Gleason, J. F.: $\mathrm{NO}_{2}$, in: OMI Algorithm Theoretical Basis Document, 4, OMI Trace Gas Algorithms, ATB-OMI-04, Version 2.0, 20 edited by:
Chance, K., 13-36, NASA Distrib. Active Archive Cent., Greenbelt, MD, USA, August 2002.

Boersma, K. F., Eskes, H. J., and Brinksma, E. J.: Error analysis for tropospheric $\mathrm{NO}_{2}$ retrieval from space, J. Geophys. Res.-Atmos., 109, D04311, doi:10.1029/2003JD003962, 2004.

Bogumil, K., Orphal, J., Flaud, J. M., and Burrows, J. P.: Vibrational progressions in the visible and near ultraviolet absorption spectrum of ozone, Chem. Phys. Lett., 349, 241-248, 2001.

Bovensmann, H., Burrows, J. P., Buchwitz, M., Frerick, J., L, S. N., Rozanov, V. V., Chance, K. V., and Goede, A. P. H.: SCIAMACHY - Mission objectives and measurement modes, J. Atmos. Sci., 56, 125-150, 1999.

Brewer, A. W., Mcelroy, C. T., and Kerr, J. B.: Nitrogen Dioxide Concentrations in the Atmosphere, Nature, 246, 129-133, doi:10.1038/246129a0, 1973.

Bucsela, E. J., Celarier, E. A., Wenig, M. O., Gleason, J. F., Veefkind, J. P., Boersma, K. F., and Brinksma, E. J.: Algorithm for $\mathrm{NO}_{2}$ vertical column retrieval from the Ozone Monitoring Instrument, IEEE Trans. Geosci. Remote S., 44, 1245-1258, 2006.

Bucsela, E. J., Krotkov, N. A., Celarier, E. A., Lamsal, L. N., Swartz, W. H., Bhartia, P. K., Boersma, K. F., Veefkind, J. P., Gleason, J. F., and Pickering, K. E.: A new stratospheric and tropospheric $\mathrm{NO}_{2}$ retrieval algorithm for nadir-viewing satellite instruments: applications to OMI, Atmos. Meas. Tech., 6, $2607-$ 2626, doi:10.5194/amt-6-2607-2013, 2013.

Burrows, J. P. and Chance, K. V.: Scanning imaging absorption spectrometer for atmospheric chartography, 1490, 146-154, 1991.

Burrows, J. P., Richter, A., Dehn, A., Deters, B., Himmelmann, S., Voigt, S., and Orphal, J.: Atmospheric remote sensing reference data from GOME - 2. Temperaturedependent absorption crosssections of $\mathrm{O}_{3}$ in the 231-794 nm range, J. Quant. Spectrosc. Ra., 61, 509-517, 1999.

Chance, K. V. and Spurr, R. J. D.: Ring effect studies: Rayleigh scattering, including molecular parameters for rotational Raman scattering, and the Fraunhofer spectrum, Appl. Optics, 36, 5224 5230, 1997.

Chipperfield, M. P.: New version of the TOMCAT/SLIMCAT offline chemical transport model: Intercomparison of stratospheric tracer experiments, Q. J. Roy. Meteor. Soc., 132, 1179-1203, doi:10.1256/qj.05.51, 2006.

Crutzen, P. J.: The influence of nitrogen oxides on the atmospheric ozone content, Q. J. Roy. Meteor. Soc., 96, 320-325, doi:10.1002/qj.49709640815, 1970.

Cuevas, E., Milford, C., Bustos, J. J., del Campo-Hernández, R., García, O. E., García, R. D., Gómez-Peláez, A. J., Ramos, R., Redondas, A., Reyes, E., Rodríguez, S., Romero-Campos, P. M., Schneider, M., Belmonte, J., Gil-Ojeda, M., Almansa, F., Alonso-Pérez, S., Barreto, A., González-Morales, Y., GuiradoFuentes, C., López-Solano, C., Afonso, S., Bayo, C., Berjón, A., Bethencourt, J., Camino, C., Carreño, V., Castro, N. J., Cruz, A. M., Damas, M., De Ory-Ajamil, F., García, M. I., Fernándezde Mesa, C. M., González, Y., Hernández, C., Hernández, Y., Hernández, M. A., Hernández-Cruz, B., Jover, M., Kühl, S. O., López-Fernández, R., López-Solano, J., Peris, A., RodríguezFranco, J. J., Sálamo, C., Sepúlveda, E., and Sierra, M.: Izaña Atmospheric Research Center Activity Report 2012-2014, edited by: Cuevas, E., Milford, C., and Tarasova, O., State Meteorological Agency (AEMET), Madrid, Spain and World Meteoro- 
logical Organization, Geneva, Switzerland, NIPO:281-15-004-2, WMO/GAW Report No. 219, 2015.

Denis, L., Roscoe, H. K., Chipperfield, M. P., Van Roozendael, M., and Goutail, F.: A new software suite for $\mathrm{NO}_{2}$ vertical profile retrieval from ground-based zenith-sky spectrometers', J. Quant. Spectrosc. Ra., 92, 321-333, 2005.

Dirksen, R. J., Boersma, K. F., Eskes, H. J., Ionov, D. V., Bucsela, E. J., Levelt, P. F., and Kelder, H. M.: Evaluation of stratospheric $\mathrm{NO}_{2}$ retrieved from the Ozone Monitoring Instrument: Intercomparison, diurnal cycle, and trending, J. Geophys. Res.-Atmos., 116, D08305, doi:10.1029/2010JD014943, 2011.

Eckert, E., von Clarmann, T., Kiefer, M., Stiller, G. P., Lossow, S., Glatthor, N., Degenstein, D. A., Froidevaux, L., GodinBeekmann, S., Leblanc, T., McDermid, S., Pastel, M., Steinbrecht, W., Swart, D. P. J., Walker, K. A., and Bernath, P. F.: Drift-corrected trends and periodic variations in MIPAS IMK/IAA ozone measurements, Atmos. Chem. Phys., 14, 25712589, doi:10.5194/acp-14-2571-2014, 2014.

Eskes, H. J. and Boersma, K. F.: Averaging kernels for DOAS totalcolumn satellite retrievals, Atmos. Chem. Phys., 3, 1285-1291, doi:10.5194/acp-3-1285-2003, 2003.

Fayt, C. and Van Roozendael M.: WinDOAS 2.1 Software User Manual, 2001.

Funke, B., Lopez-Puertas, M., Stiller, G., von Clarmann, T. and Gacia, R.: Stratospheric NOy: global budget and vaiability in 20022012 from MIPAS observations, in: Regional SPARC workshop, Granada, Spain, 13-16 January 2015.

García, O. E., Schneider, M., Redondas, A., González, Y., Hase, F., Blumenstock, T., and Sepúlveda, E.: Investigating the longterm evolution of subtropical ozone profiles applying groundbased FTIR spectrometry, Atmos. Meas. Tech., 5, 2917-2931, doi:10.5194/amt-5-2917-2012, 2012.

Gil, M.: UV/VIS Izaña Total Column, available at: ftp://ftp.cpc. ncep.noaa.gov/ndacc/station/izana/ames/uvvis/, 2008-2013.

Gil, M., Yela, M., Gunn, L. N., Richter, A., Alonso, I., Chipperfield, M. P., Cuevas, E., Iglesias, J., Navarro, M., Puentedura, O., and Rodríguez, $\mathrm{S}$.: $\mathrm{NO}_{2}$ climatology in the northern subtropical region: diurnal, seasonal and interannual variability, Atmos. Chem. Phys., 8, 1635-1648, doi:10.5194/acp-8-1635-2008, 2008.

Gil-Ojeda, M., Navarro-Comas, M., Gómez-Martín, L., Adame, J. A., Saiz-Lopez, A., Cuevas, C. A., González, Y., Puentedura, O., Cuevas, E., Lamarque, J.-F., Kinninson, D., and Tilmes, S.: $\mathrm{NO}_{2}$ seasonal evolution in the north subtropical free troposphere, Atmos. Chem. Phys., 15, 10567-10579, doi:10.5194/acp-1510567-2015, 2015.

Gisi, M., Hase, F., Dohe, S., and Blumenstock, T.: Camtracker: a new camera controlled high precision solar tracker system for FTIR-spectrometers, Atmos. Meas. Tech., 4, 47-54, doi:10.5194/amt-4-47-2011, 2011.

Gomez, L., Navarro-Comas, M., Puentedura, O., Gonzalez, Y., Cuevas, E., and Gil-Ojeda, M.: Long-path averaged mixing ratios of $\mathrm{O}_{3}$ and $\mathrm{NO}_{2}$ in the free troposphere from mountain MAXDOAS, Atmos. Meas. Tech., 7, 3373-3386, doi:10.5194/amt-73373-2014, 2014.

Greenblatt, G. D., Orlando, J. J., Burkholder, J. B., and Ravishankara, A. R.: Absorption Measurements of Oxygen Between 330 and 1140 nm, J. Geophys. Res., 95, 18577-18582, 1990.

Gruzdev, A. N. and Elokhov, A. S.: Validating $\mathrm{NO}_{2}$ measurements in the vertical atmospheric column with the OMI instrument aboard the EOS Aura satellite against ground-based measurements at the Zvenigorod Scientific Station, Izv. Atmospheric Ocean. Phys., 45, 444-455, doi:10.1134/S0001433809040057, 2009.

Harder, J. W. and Brault, J. W.: Atmospheric measurements of water vapor in the 442-nm region, J. Geophys. Res., 102, 6245-6252, doi:10.1029/96JD01730, 1997.

Hase, F., Blumenstock, T., and Paton-Walsh, C.: Analysis of the instrumental line shape of high-resolution Fourier transform IR spectrometers with gas cell measurements and new retrieval software, Appl. Opt., 38, 3417, doi:10.1364/AO.38.003417, 1999.

Hase, F., Hannigan, J. W., Coffey, M. T., Goldman, A., Höpfner, M., Jones, N. B., Rinsland, C. P. and Wood, S. W.: Intercomparison of retrieval codes used for the analysis of high-resolution, groundbased FTIR measurements, J. Quant. Spectrosc. Ra., 87, 25-52, doi:10.1016/j.jqsrt.2003.12.008, 2004.

Hendrick, F., Barret, B., Van Roozendael, M., Boesch, H., Butz, A., De Mazière, M., Goutail, F., Hermans, C., Lambert, J.C., Pfeilsticker, K., and Pommereau, J.-P.: Retrieval of nitrogen dioxide stratospheric profiles from ground-based zenithsky UV-visible observations: validation of the technique through correlative comparisons, Atmos. Chem. Phys., 4, 2091-2106, doi:10.5194/acp-4-2091-2004, 2004.

Hendrick, F., Mahieu, E., Bodeker, G. E., Boersma, K. F., Chipperfield, M. P., De Mazière, M., De Smedt, I., Demoulin, P., Fayt, C., Hermans, C., Kreher, K., Lejeune, B., Pinardi, G., Servais, C., Stübi, R., van der A, R., Vernier, J.-P., and Van Roozendael, M.: Analysis of stratospheric $\mathrm{NO}_{2}$ trends above Jungfraujoch using ground-based UV-visible, FTIR, and satellite nadir observations, Atmos. Chem. Phys., 12, 8851-8864, doi:10.5194/acp-12-88512012, 2012.

Hermans, C., Vandaele, A. C., Carleer, M., Fally, S., Colin, R., Jenouvrier, A., Coquart, B., and Mérienne, M. F., Absorption Cross-Sections of Atmospheric Constituents: $\mathrm{NO}_{2}, \mathrm{O}_{2}$ and $\mathrm{H}_{2} \mathrm{O}$, Environ. Sci. Poll. Res., 6, 151-158, doi:10.1007/BF02987620, 1999.

Kerr, J. B. and McElroy, C. T.: Measurement of stratospheric nitrogen dioxide from the AES stratospheric balloon program, Atmosphere, 14, 166-171, 1976.

Lambert, J.-C., Granville, J., Van Roozendael, M., Sarkissian, A., Goutail, F., and Muller, J.: A climatology of $\mathrm{NO}_{2}$ profile for improved Air Mass Factors for ground-based vertical column measurements, in Fifth European workshop on stratospheric ozone, 3-6, Saint Jean de Luz, France, 1999.

Lambert, J.-C., Pinardi, G., Granville, J., Clemer, K., Delcloo, A., Valks, P., and Hao, N.: GOME-2 $\mathrm{NO}_{2}$ total column validation report, SAF/O3M/IASB/VR/NO2/095, available at: http://o3msaf.fmi.fi/docs/vr/Validation_Report_NTO_OTO_ NO2_Feb_2011.pdf (last access: 9 September 2016), February 2011 .

Levelt, P. F., van den Oord, G. H., Dobber, M. R., Malkki, A., Visser, H., de Vries, J., Stammes, P., Lundell, J. O. V., and Saari, H.: The ozone monitoring instrument, IEEE T. Geosci. Remote, 44, 1093-1101, 2006.

Liley, J. B., Johnston, P. V., McKenzie, R. L., Thomas, A. J., and Boyd, I. S.: Stratospheric $\mathrm{NO}_{2}$ variations from a long time series at Lauder, New Zealand, J. Geophys. Res., 105, 11633-11640, 2000 . 
Marchenko, S., Krotkov, N. A., Lamsal, L. N., Celarier, E. A., Swartz, W. H., and Bucsela, E. J.: Revising the slant column density retrieval of nitrogen dioxide observed by the Ozone Monitoring Instrument. J. Geophys. Res.-Atmos., 120, 5670-5692, doi:10.1002/2014JD022913, 2015.

Noxon, J. F.: Nitrogen dioxide in the stratosphere and troposphere measured by ground-based absorption spectroscopy, Science, 189, 547-549, doi:10.1126/science.189.4202.547, 1975.

Peters, E., Wittrock, F., Großmann, K., Frieß, U., Richter, A., and Burrows, J. P.: Formaldehyde and nitrogen dioxide over the remote western Pacific Ocean: SCIAMACHY and GOME-2 validation using ship-based MAX-DOAS observations, Atmos. Chem. Phys., 12, 11179-11197, doi:10.5194/acp-12-111792012, 2012.

Platt, U. and Stutz, J.: Differential optical absorption spectroscopy: principles and applications, Springer, Berlin, ISBN-13: 978-3540-75776-4, 2008.

Puentedura, O., Gil, M., Saiz-Lopez, A., Hay, T., Navarro-Comas, M., Gómez-Pelaez, A., Cuevas, E., Iglesias, J., and Gomez, L.: Iodine monoxide in the north subtropical free troposphere, Atmos. Chem. Phys., 12, 4909-4921, doi:10.5194/acp-12-49092012, 2012.

Richter, A.: Stratospheric $\mathrm{NO}_{2}$ data, available at: http://www.iup. uni-bremen.de/doas/scia_no2_data_acve.htm, 2007.

Richter, A. and Burrows, J. P.: Retrieval of tropospheric $\mathrm{NO}_{2}$ from GOME measurements, Adv. Space Res., 29, 1673-1683, 2002.

Rodgers, C. D.: Inverse methods for atmospheric sounding: theory and practice, Reprinted, World Scientific, Singapore, ISBN-13: 978-9810227401, 2004.

Rothman, L. S., Gordon, I. E., Barbe, A., Benner, D. C, Bernath, P. F., Birk, M., Boudon, V., Brown, R., Campargue, A., Champion, J.-P., Chance, V, Coudert, L. H., Dana, V., Devi, V. M., Sally, S., Flaud, J.-M., Gamache, R. R., Goldman, A., Jacquemart, D., Kleiner, I., Lacome, N., Lafferty,W. J., Mandin, J.-Y., assie, S. T., Mikhailenko, S. N., Miller, C. E., Moazzen-Ahmadi, N., Naumenko, O. V., Nikitin, A. V., Orphal, J., Perevalov, V. I., Perrin , A., Predoi-Cross, A., Rinsland, C. P., Rotger, M., Simeckova, M., Smith, M. A. H., Sung, K., Tashkun, S. A., Tennyson J., Toth, R. A., Vandaele, A. C., and Vander Auwera, J.: The HITRAN 2008 molecular spectroscopic database, J. Quant. Spectrosc. Ra., 110, 533-572, 2009.

Sarkissian, A., Roscoe, H. K., Fish, D., Van Roozendael, M., Gil, M., Chen, H. B., Wang, P., Pommereau, J.-P., and Lenoble, J.: Ozone and $\mathrm{NO}_{2}$ air-mass factors for zenith-sky spectrometers: Intercomparison of calculations with different radiative transfer models Geophys. Res. Lett., 22, 1113-1116, 1995.

Schneider, M., Blumenstock, T., Chipperfield, M. P., Hase, F., Kouker, W., Reddmann, T., Ruhnke, R., Cuevas, E., and Fischer, H.: Subtropical trace gas profiles determined by ground-based FTIR spectroscopy at Izaña $\left(28^{\circ} \mathrm{N}, 16^{\circ} \mathrm{W}\right)$ : Five-year record, error analysis, and comparison with 3-D CTMs, Atmos. Chem. Phys., 5, 153-167, doi:10.5194/acp-5-153-2005, 2005.

Seidel, D. J., Li, J., Mears, C., Moradi, I., Nash, J., Randel, W. J., Saunders, R.,Thompson, D. W. J., and Zou, C. Z..: Stratospheric temperature changes during the satellite era, J. Geophys. Res.Atmos., 121, 664-681, doi:10.1002/2015JD024039, 2016.
Sussmann, R., Stremme, W., Burrows, J. P., Richter, A., Seiler, W., and Rettinger, M.: Stratospheric and tropospheric $\mathrm{NO}_{2}$ variability on the diurnal and annual scale: a combined retrieval from ENVISAT/SCIAMACHY and solar FTIR at the Permanent Ground-Truthing Facility Zugspitze/Garmisch, Atmos. Chem. Phys., 5, 2657-2677, doi:10.5194/acp-5-2657-2005, 2005.

Syed, M. Q. and Harrison, A. W.: Seasonal trend of stratospheric $\mathrm{NO}_{2}$ over Calgary, Can. J. Phys., 59, 1278-1279, doi:10.1139/p81-166, 1981.

Vandaele, A. C., Hermans, C., Simon, P. C., Carleer, M., Colin, R., Fally, S., Mérienne, M. F., Jenouvrier, A., and Coquart, B.: Measurements of the $\mathrm{NO}_{2}$ absorption crosssection from $42000 \mathrm{~cm}^{-1}$ to $10000 \mathrm{~cm}^{-1}(238-1000 \mathrm{~nm})$ at $220 \mathrm{~K}$ and $294 \mathrm{~K}$, J. Quant. Spectrosc. Ra., 59, 171-184, doi:10.1016/S0022-4073(97)00168-4, 1998.

van Geffen, J. H. G. M., Boersma, K. F., Van Roozendael, M., Hendrick, F., Mahieu, E., De Smedt, I., Sneep, M., and Veefkind, J. P.: Improved spectral fitting of nitrogen dioxide from OMI in the 405-465 nm window, Atmos. Meas. Tech., 8, 1685-1699, doi:10.5194/amt-8-1685-2015, 2015.

Van Roozendael, M. and Hendrick, F.: Recommendations for $\mathrm{NO}_{2}$ column retrieval from NDACC zenith-sky UV-VIS spectrometers, NDACC 2012, available at: http://uv-vis.aeronomie.be/ groundbased/NDACC_UVVIS-WG_NO2settings_v3.pdf, (last access: 14 July 2016), 2012.

Van Roozendael, M., Spurr, R., Loyola, D., Lerot, C., Balis, D., Lambert, J.-C., Zimmer, W., van Gent, J., van Geffen, J., Koukouli, M., Granville, J., Doicu, A., Fayt, C., and Zehner, C.: Sixteen years of GOME/ERS-2 total ozone data: The new direct-fitting GOME Data Processor (GDP) version 5 - Algorithm description, J. Geophys. Res., 117, D03305, doi:10.1029/2011JD016471, 2012.

Vaughan, G., Roscoe, H. K., Bartlett, L. M., O'Connor, F., Sarkissian, A., Van Roozendael, M., Lambert, J.-C., Simon, P. C., Karlsen, K., Kaestad Hoiskar, B. A., Fish, D. J., Jones, R. L., Freshwater, R., Pommereau, J.-P., Goutail, F., Andersen, S. B., Drew, D. G., Hughes, P. A., Moore, D., Mellqvist, J., Hegels, E., Klupfel, T., Erle, F., Pfeilsticker, K., and Platt, U.: An intercomparison of ground-based UV-visible sensors of ozone and $\mathrm{NO}_{2}$, J. Geophys. Res., 102, 1411-1422, 1997.

Wetzel, G., Bracher, A., Funke, B., Goutail, F., Hendrick, F., Lambert, J.-C., Mikuteit, S., Piccolo, C., Pirre, M., Bazureau, A., Belotti, C., Blumenstock, T., De Mazière, M., Fischer, H., Huret, N., Ionov, D., López-Puertas, M., Maucher, G., Oelhaf, H., Pommereau, J.-P., Ruhnke, R., Sinnhuber, M., Stiller, G., Van Roozendael, M., and Zhang, G.: Validation of MIPASENVISAT $\mathrm{NO}_{2}$ operational data, Atmos. Chem. Phys., 7, $3261-$ 3284, doi:10.5194/acp-7-3261-2007, 2007. 